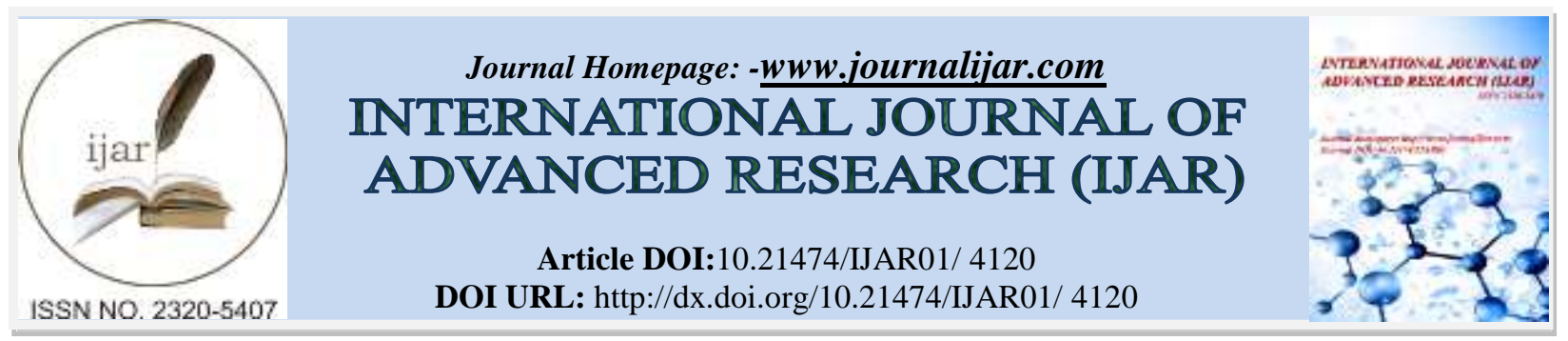

RESEARCH ARTICLE

\title{
SPATIAL ASPECTS OF THE COMMUNICATION BETWEEN MASCULINE AND FEMININE IN DINO BUZZATI'S PROSE
}

Iuliana David.

Assistant Professor, PhD, "Ovidius" University of Constanţa.

\section{Manuscript Info}

Manuscript History

Received: 12 March 2017

Final Accepted: 14 April 2017

Published: May 2017

Key words:-

gender communication, perception of space, barrier, distance, labyrinth, Dino Buzzati

\section{Abstract}

The current paper aims to show that the gender relations in the Buzzatian prose are most often described in spatial terms and analyzes how communication between masculine and feminine works. The approach takes into account the multiple spatial modalities that in Dino Buzzati's texts mark the difference between the two categories, including aspects regarding the existence of specific options and perceptions in relation to the surrounding universe. The article registers a varied inventory of obstacles and distortions spatially associated to the process of communication, such as barriers, distances, complicate forms and divergent orientations.

Copy Right, IJAR, 2016,. All rights reserved.

\section{Introduction:-}

In order to understand the world reconstituted in the text as a human environment, the configuration of the relationship between masculine and feminine is also relevant, and the spatial elements-particularly important throughout Dino Buzzati's prose - are closely related to this relationship, as this article will attempt to demonstrate. Even if generally it is a reduced or secondary presence of the feminine element in the author's texts, the way in which the communication between the representatives of the two categories and the way they interconnect in the context contribute to shaping a specific vision on life. The topic of relating the two types of characters to space has been approached by literary criticism from the perspective of the dynamics and organization in specific action areas-Felix Siddell (152-174) points out the significant differences that appear in this sense, and less from the point of view of the spatial component of the relational and communication process.

The existence of a barrier that separates the speakers marks spatially, in some texts, the difficulty of communication between men and women in the Buzzatian universe. Such is the case of the veil that seems to interpose between the protagonist of the novel Il deserto dei Tartari and his mother or between himself and his girlfriend, when he returns home in a short leave from the garrison where he has been appointed and where he is living: "Ma qualche cosa si era messo veramente fra di loro, un velo indefinibile e vago che non voleva dissolversi; forse esso era cresciuto lentamente, durante la lunga separazione, giorno per giorno, dividendoli, e nessuno dei due lo sapeva" (Buzzati, 2006: 156).

The whole framework of the meeting with Maria Vescovi at her home, in the above mentioned example, which is permanently reiterated, is suggestive for the configuration of the relationship between the two characters. The difficulty in finding the right words or tone, the unpleasant feeling of falsity and coldness in conversation, the discussion based only on conventional replies, which become torturing, have their correspondent in the bare piano sounds-which seem endless, "repeating with a resigned detachment an old story, once beloved"-, and in the 
contrasting images between the girl's idyllic garden and the arid landscape around the Fortress, which highlight the difference between the two worlds to which the speakers belong. The space, that could have been initially imagined as favourable for transmitting thoughts and feelings, at the limit of words, as Alain Le Prado states, able to dispense the characters from language (94), actually translates the difficulty of interconnection.

The cloak in the homonymous story functions in a similar way to the veil. The cloak tightly wraps the character, who refuses to take it off, to the desperation of the mother, and stands between the mother and the son, reinforcing iconically the blocked communication between the two and the impossibility of restoring an authentic connection between them. The piece of clothing traces a boundary between the speakers and causes a discontinuity between plans, by preventing the visual access to what is beyond the appearance; it is at the same time the element whose presence influences the entire meeting. Giovanni's few and difficultly articulated words, the mother's unexpressed questions, the lack of topics of discussion - all under the sign of the cloak - lead to the same acknowledgement of the gap emerged between the two categories of characters and of the inability to find a common language. There can be noticed the markers of a non-communicability specific to the Buzzatian characters whose own world is destined to remain self-contained, also revealed by their incapacity to smile (Mignon 22), obvious especially in the affective relationship between mother and son, both in Il deserto dei Tartari ("perché non riusciva sorridere con la doverosa spensieratezza mentre salutava la madre?", Buzzati, 2006: 4), and in "Il mantello" ("perfino a sorridere sembrava facesse fatica', "continuava a sorridere con grandissimo sforzo", Buzzati, 2002: 71, 75). A coherent flow cannot be established even at the visual level, where the characters' thoughts and feelings are mainly revealed, as the complex game of their exchanged glances always includes as landmarks the cloak and the window through which the yard can be seen and, beyond it, the individual in black clothes who wanders.

The difficulty of real communication with female characters is announced, in Il deserto dei Tartari, by Drogo's attempt to resume the contact with his mother in writing. This act proves to be extremely problematic, as his sincere thoughts and emotions cannot be embodied in the words that compose the letter for his mother, but are artificially reformulated and even translated into a message with a contrary sense, adapted to the addressee's expectances. The process of writing is rhythmized by the alternative spatial references - on the one hand to the newly discovered world of the Fortress, and on the other hand to home-which are decisive for the transformation of the message. The text ends symbolically with the echoes of the periodic shouts of the sentinels at Bastiani, which then slowly fade away, anticipating somehow the sonorous distortions of Drogo's late arrival from the ball during his leave, when the ambient sounds replace illusorily the words, and the rattle of a cart is mistaken for the mother's voice. The alteration of the communication channel between the two characters is indicated through the effects of the empty space, through the marks in the paradigm of reflection and absence (Geerts 166), demonstrating once again the register of incomprehension and alienation that dominate these sequences. "«Buonanotte, mamma », egli disse passando nel corridoio e dalla stanza, al di là della porta, gli parve che come al solito, come nei giorni lontani quando rincasava a notte alta, gli rispondesse un suono confuso, una voce amorevole, anche se grondante di sonno. [...] Nello stesso istante capì di avere scambiato il rotolio di una carrozza lontana con la cara voce. In verità la mamma non aveva risposto, i passi notturni del figlio più non la potevano destare come una volta [...]" (Buzzati, 2006: 152)

The same problem in terms of the written discourse appears when Drogo tries to write to Mary-the girl who "may one day become his wife" - and just after two lines he interrupts this action because of a stronger spatial temptation: to look at the fascinating and promising territory that opens beyond the Fortress, towards the north.

The masculine/ feminine rupture may take the spatial expression of the symbolic distance between the two characters, otherwise physically close. An abyss seems to open wide between Giovanni Drogo and Maria Vescovi: "Adesso erano di nuovo lontani, fra essi si apriva un vuoto, invano allungavano le mani per toccarsi, ad ogni minuto la distanza aumentava" (Buzzati, 2006: 160). Similarly, an immense distance, almost impossible to cover, appears between the two characters of "Inviti superflui": "Ma tu-adesso ci penso-sei troppo lontana, centinaia e centinaia di chilometri difficili a valicare", Buzzati, 2002: 202). This corresponds to a fundamental difference between the representatives of the two genders, manifested also by different types of perception and spatial orientation. The places full of charm and excitement, of hopes and memories, of presentiments and hidden calls, chosen by the former, are not understood as such by the latter ("tu ti guarderesti attorno senza capire, ho paura", Buzzati, 2002: 200-201), and the concrete things that attract her attention are indifferent to him. The two irreconcilable modes of reference to the surrounding universe and the two opposite directions of the eye attributed to the protagonists in "Inviti superflui" are presented in counterpoint by the same voice, the masculine one. They do not allow the characters to reach the so-called poetry of souls and to merge into the harmony of becoming one, highlighting the 
essential solitude of the individual and the futility of any attempt of intimacy: "Ma tu [...] invece di guardare il cielo di cristallo e gli aerei colonnati battuti dall'estremo sole, vorrai fermarti a guardare le vetrine, gli ori, le ricchezze, le sete, quelle cose meschine [...] Ed io sarei solo. (Buzzati, 2002: 201)

The difference is noticeable at the level of verbal communication, where one's topics appear uninteresting and meaningless to the other ("E non diresti 'Che bello!', ma altre povere cose che a me non importano. Perché purtroppo sei fatta cosi”, Buzzati, 2002: 201) and each of them seems to speak another language ("[...] se non capirai ciò che ti dico, se parlerai di fatti a me strani”, Buzzati, 2002: 203). It is also perceptible in the sensitive plan of nonverbal communication, which cannot be achieved precisely because of the different wavelengths to which the two are connected. '[...] né l'anima tua sa parlare alla mia in silenzio, né riconosci all'ora giusta l'incantesimo della città, né le speranze che scendono dal settentrione. Tu preferisci le luci, la folla, gli uomini che ti guardano, le vie dove dicono si possa incontrare la fortuna. Tu sei diversa da me [...]” (Buzzati, 2002: 200).

A different spatial perception of women is also referred to in "L'uccisione del drago", by emphasizing the impression that the surrounding universe makes on Maria, the wife of the provincial governor, who accompanies him and his companions in the expedition for the dragon hunting. The only female character that takes part in this action, Maria is also the only one in the group who deeply feels the hostility of the environment in which they penetrate, the sadness and loneliness that emanates from it. The desolate and threatening, arid and lifeless places trigger for her gloomy feelings and a sense of fear and anxiety that she cannot share with the other members of the expedition because of an incongruity of communication. This is manifested at the level of the sight, which usually mediates the contact with the space and is also the channel of expression of characters' emotions and feelings. "La bella Maria taceva. Ogni intraprendenza era in lei svanita. Con quanta gioia sarebbe tornata subito indietro. Ma non osava dirlo a nessuno. I suoi sguardi percorrevano le pareti attorno, le antiche e le nuove frane, i pilastri di terra rossa che sembrava dovessero ad ogni momento cadere. Il marito, il conte Gerol, i due naturalisti, i cacciatori gli parevano pochi, pochissimi, con tanta solitudine" (Buzzati, 2002: 83).

The one that separates the speakers is sometimes a labyrinthic multiplication of the rooms and obstacles, as in the case of Drogo and the girl in purple. He begins to flirt with her during the ball in the city but he is prevented from continuing the conversation with her and is separated from the girl by the intervention of the host, and by the force of the space and of the multitude of objects. "[...] quand'ecco il padrone di casa lo chiamò per mostrargli dettagliatamente il palazzo, lo trasse per certi labirinti e cunicoli, lo tenne relegato nella biblioteca, lo obbligò a considerare pezzo per pezzo una collezione d'armi [...] Quando Drogo riuscì a liberarsi, ansioso di tornare alle danze, le sale si erano vuotate, la ragazza vestita di viola era scomparsa, probabilmente già tornata a casa" (Buzzati, 2006: 151).

The labyrinthic representation is even more evident in the novels Un amore and Il grande ritratto. The more the woman is integrated into such a universe, the communication becomes subject to the complicated itinerary implied by this association. And, unlike the rest of the Buzzatian creation, these texts embed more than just a fugitive, barely sketched feminine presence.

Laide, the low morality girl in Un amore, for whom Antonio Dorigo experiences a late passion, embodies the city she lives in, and its side which is "plebeian, nocturnal, cheerful, vicious, dementially active and self-confident," also connected to La Storta district. Laide is characterized metonymically as an anthropomorphic megalopolis, capturing in her being the composite spirit of the city (Cosmin 256). She is perceived as a product of this urban environment, but the city from which she appears is also the one that can swallow her, absorbing her as a swirling space: "la nera Milano antica e tenebrosa sta per riprenderla e inghiottirla, lei sparirà nel labirinto", Buzzati, 1963: 313). The image of the emergence of the fluid urban substance, from its obscure depths, has its reverse in the image of the immersion in its dizzying whirlpool, of the retreat in the insalubrious tumult of a heteroclite, fermenting world, and of the centripetal movement towards its hidden core. "A poco a poco lei si stacca da lui, esce dalla sua casa e dalla sua vita, col suo impavido passo ecco che si incammina verso l'enigmatico cuore della sua città che nessuno di solito vede, fra squallidi e fortissimi scenari, attraverso gli scrostati fumigosi cortili stillanti di pioggia, fra i riverberi del lusso, negli antri degli antichi palazzi, giù per gli interminabili corridoi di linoleum negli angoli delle catacombe del vizio, fra cigolii de pneumatici, frastorno di tornii, urla, pianti e risate, andirivieni di uomini instancabili e stanchi, affrettati baci, ombre di avventurieri controluce, camici verdi di chirurghi, agguati telefonici, un folle rimescolio di desideri, sforzi e illusioni che brucia confuso nella folla la quale arriva riparte si mescola incalza si rompe e sparisce mentre un'altra identica folla si avventa e sprofonda nel gorgo" (Buzzati, 1963: 290-291). 
The approach and departure from Laide are translated by the opening and closing of that world that chronicles and guides do not speak about, and the relationship with her follows the same labyrinthic pattern as that of the universe to which she is assimilated, with searches and delusions, with contradictory returns and movements, from which emerges the idea of a different and hard to understand essence. The amorous adventure is permanently doubled by the perception and reflection on space, the representation of the girl by that of the world to which she is circumscribed - which is no wonder if we take into account that Dorigo is an architect and hence he models and orders the space (Scarsella 423).

Laura of Il grande ritratto identifies herself with a labyrinth, and her body, equivalent to a place, is made up of a protean ensemble of architectural elements. The beloved woman, dead in an accident, is rebuilt by Professor Endriade, by using cybernetics as a "magical" instrument of action (Ionescu 175), in an anthropomorphic structure, under the form of a complicated construction. Her physiognomy is configured from a number of apparently irregular material components, "from a clutter of walls, edges, geometric profiles"."[...] Tutto era stato invaso e sopraffatto da un accavallamento di edifici simili a silos, torri, mastabe, muraglioni, esili ponti, barbacani, caselli, casematte, bastioni, che si inabissavano in vertiginose geometrie. Come una città si fosse abbattuta sui fianchi di un burrone" (Buzzati, 1974: 70).

This spatial figure reflects the woman's inaccessibility, in her lifetime, "distant, strange, imprisoned in desires and untouchable thoughts," a personality whose content could have never been penetrated, always inducing the man the feeling that he misses something essential. It is an aspect that remains valid for the new variant, despite the fact that the reconstruction is based on scientific formulas, under the apparently predictable form of an effective machine. Her mysterious thoughts cannot be captured by devices, her being cannot really be controlled even in this immobile, object hypostasis, remaining alien and indecipherable: "Di nuovo la sentivo vicina, palpitante, estranea e irraggiungibile" (Buzzati, 1974: 114). Hence the permanent state of tension and anxiety and the torment of fears, suspicions and doubts that define Endriade's relationship with Laura.

The scientist's endeavor to decipher her coded language, the messages emitted through vibrations and electronic combinations, does not entirely succeed, because communication is problematic, as usual. Without a human voice, the weird creature communicates through non-articulated sounds, through whispers and humming, from which emerge modulations which seem to be, to some extent, a voice. The labyrinthic figure also illustrates this process of complicated and misleading shapes, conceals and distortions, and the woman is irrevocably indicated as "other" (Siddell 161).

\section{Conclusions:-}

The spatial references designate, thus, in one form or another, the definitive position of the masculine and feminine in distinct fields, irreducible to a common language, highlighting the difficulty or suspension of the connection between the two categories, the existence of barriers or incongruities.

\section{Works Cited:-}

1. Buzzati, Dino (2006): Il deserto dei Tartari. Milano: Mondadori.

2. ---. Il grande ritratto (1974). Mondadori: Milano.

3 . ---. Sessanta racconti (2002). Mondadori: Milano.

4. ---. Un amore (1963). Mondadori: Milano.

5. Cosmin, Smaranda (2002): „Postfaţă”. Dino Buzzati. O dragoste. Iaşi: Polirom, pp. 253-260.

6. Geerts, Walter (1982): „Forma, spazio, visione”. In Alvise Fontanella (ed.). Dino Buzzati - Atti del Convegno Internazionale di Studio promosso dalla Fondazione Cini. Firenze: Olschki, pp. 157-167.

7. Ionescu, Cornel Mihai (2003): „L(Aura). De la agalma la golem”. Postfaţă la Dino Buzzati. Marele portret. Iaşi: Polirom, pp. 173-177.

8. Le Prado, Alain (1981): „Figures et effets de spatialisation dans «Le désert des tartares». Etude d'un dispositif libidinal". Lectures des «Le désert des tartares» de Buzzati. Paris: Belin, pp. 87-110.

9. Mignone, Mario (1981): Anormalità e angoscia nella narrativa di Dino Buzzati. Ravenna: Longo.

10. Scarsella, Alessandro (1992). „Buzzati e il mito della città nella letteratura italiana contemporanea”. In Nella Giannetto (ed.). Il pianeta Buzzati: Atti del Convegno Internazionale, Milano: Mondadori, pp. 415-429.

11. Siddell, Felix (2006). Death or deception: sense of place in Buzzati and Morante. Leicester: Troubador. 